\title{
Physical fitness of 9 year olds in England: related factors
}

\author{
Shogo Kikuchi, Roberto J Rona, Susan Chinn
}

\begin{abstract}
Study objective - To examine the influence of social factors, passive smoking, and other parental health related factors, as well as anthropometric and other measurements on children's cardiorespiratory fitness.

Design - This was a cross sectional study. Setting-The analysis was based on 22 health areas in England.

Participants - The subjects were 299 boys and 282 girls aged 8 to 9 years. Parents did not give positive consent for $15 \%$ of the eligible sample. A further $25 \%$ of the eligible sample did not participate because the cycle-ergometer broke down, study time was insufficient, or they were excluded from the analysis because they were from ethnic minority groups or had missing data on one continuous variable.
\end{abstract}

Measurements and main results - Cardiorespiratory fitness was determined using the cycle-ergometer test. It was measured in terms of PWC85\% - that is, power output per body weight (watt/kg) assessed at $85 \%$ of maximum heart rate. The association between children's fitness and biological and social factors was analysed in two stages. Firstly, multiple logistic analysis was used to examine the factors associated with the children's ability to complete the test for at least four minutes. Secondly, multiple linear regression analysis was used to examine the independent association of the factors with PWC85\%. In the logistic analysis, shorter children, children with higher blood pressure, and boys with a larger sibship size had poorer fitness. In the multiple regression analysis, only height $(p<0 \cdot 001)$ was positively associated, and the sum of skinfold thicknesses at four sites $(p=0.001)$ was negatively associated with fitness in both sexes. In girls, a positive association was found with pre-exercise peak expiratory flow rate $(p<0.05)$, and there were negative associations with systolic blood pressure $(p<0.05)$ and family history of heart attack $(p<0 \cdot 05)$. In boys an association was found with skinfold distribution and fitness $(p<0.05)$, so that children with relatively less body fat were fitter. Social and health behaviour factors such as father's social class, father's employment status, or parents' smoking habits were unrelated to child's fitness.

Conclusion-Height and obesity are strongly associated, and systolic blood pressure to a small extent, with children's fitness, but social factors are unrelated.

(f Epidemiol Community Health 1995;49:180-185)

Although there is some information about the factors that affect physical fitness and physical activity of British adults ${ }^{1}$ there is little information on adolescents ${ }^{2}$ and no information on younger children. The methodology for assessing physical activity in children is cumbersome, labour intensive, ${ }^{34}$ and of uncertain validity. Cardiorespiratory fitness is rarely measured in children under the age of 11 . However, physical activity and physical fitness may play an important role in the prevention of chronic diseases in adults. ${ }^{5}$ Our understanding of the factors that may affect its level in children may be relevant to modify physical activity in childhood as claims are made that the physical fitness and activity of British children is poor and may be deteriorating over time. ${ }^{3}$

In the national study of health and growth (NSHG), a monitoring system to assess nutritional status in primary school children, analyses have been carried out to assess the factors that influence height, weight for height, and triceps skinfold thickness in British children, ${ }^{67}$ and the changes of these anthropometric measurements over time. ${ }^{89}$ In 1992, a set of measurements were introduced in the study to assess coronary heart disease risk factors in 9 year olds. Cardiorespiratory fitness was assessed using the cycle-ergometer test. PWC85\%, that is power output against load at $85 \%$ of the maximum heart rate, was measured in about 600 children in England. In the analysis currently undertaken we examine the influence of social factors, parental health behaviour in terms of passive smoking and other health related factors, and other measurements on children's fitness.

\section{Subjects and methods}

The NSHG monitors nutritional status in three samples: an English representative sample, a Scottish representative sample, and an inner city area sample. ${ }^{6}$ In 1992 , the cycle-ergometer test was carried out in the English representative sample. Since the subjects belonging to ethnic groups other than white were around $5 \%$ of the total the current analyses were restricted to white children to eliminate any influence of ethnicity.

The test was carried out in the "rising nine children" - that is, children born between 1 


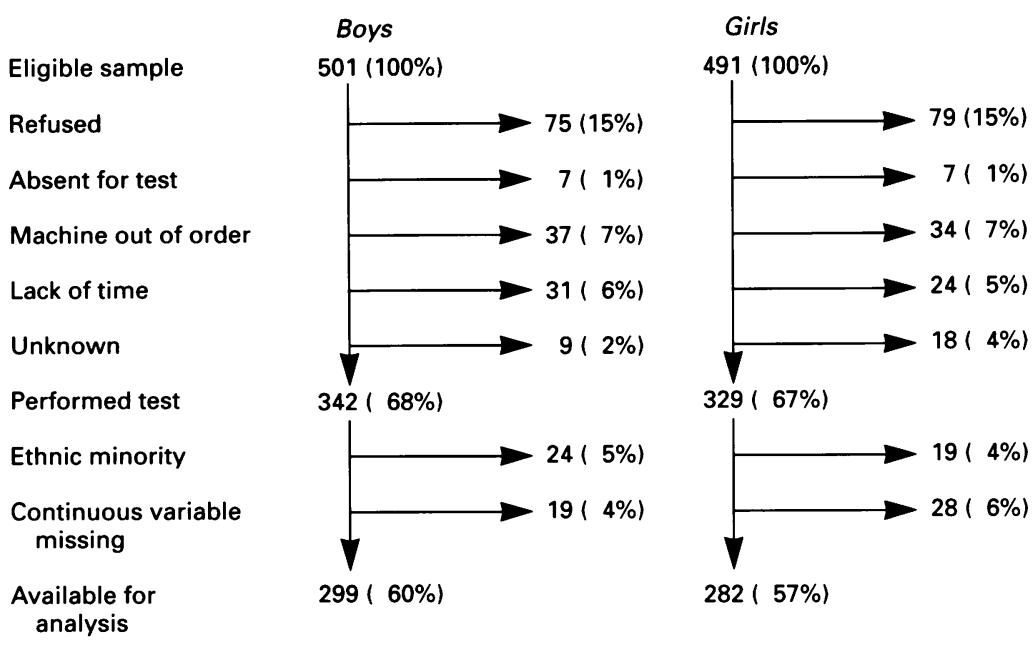

Figure Flow chart showing the reasons for exclusion in the analyses

September 1982 and 31 August 1983 if assessed between April and July 1992 or between 1 September 1983 and 31 August 1984 if measured between September and November 1992. As time in the school was limited at each school and all the eligible children could not be tested, and to ensure that the fieldworker did not bias the sample towards children who were keen on physical exercise, we randomised study areas. This meant that the fieldworkers were directed to test children starting from the beginning or the end of the alphabetical list according to random allocation. The study was carried out in 22 English areas. Boys and girls were invited to participate. An explanation of the measurements was given to the parents and they had to give positive consent for the child to take part in the tests. The parents or guardian were asked to complete a questionnaire on sociodemographic information, health status in the family, and the child.

As a marker of physical fitness, PWC $85 \%$ was measured by cycle-ergometer test as recommended by Eurofit. ${ }^{10}$ In Eurofit, the test was standardised for adolescents and the power output at $85 \%$ corresponds to a pulse rate of 170 . In the 9 year olds, $85 \%$ corresponds approximately to a pulse rate of 185 . The child was asked to ride the cycle for six minutes. The load was increased every two minutes following the Eurofit instructions. Children were asked to stop the test if their heart rate reached more than $196 / \mathrm{min}$, if they became too exhausted, or if they felt some unusual discomfort. Children whose heart rate did not reach more than 187/ min at the third load continued the test for another two minutes with an increased fourth load. PWC $85 \%$ was calculated using the data at the last two loads by linear interpolation:

$$
\text { PWC } 85 \%=\{(W 2-W 1) /(\text { HR2 }- \text { HR1 }) *
$$$$
(185-\mathrm{HR} 2)+\mathrm{W} 2\} / \mathrm{BW} \text { (watt/kg) }
$$

where 185 is approximately $85 \%$ of maximum heart rate, and HR2 and HR1 are heart rates at load 2 (the last load) and 1(the load before the last) respectively. W2 and W1 are workloads in watts at loads 2 and 1 respectively and BW is body weight in $\mathrm{kg}$.

The explanatory factors which were used as categorical variables in this study (other than PWC85\%) were: number of siblings, wheezing, mother's education, one parent family or not, father's employment status, father's social class, mother's smoking during pregnancy, father's home smoking, mother's home smoking, parents' total home smoking, family history of heart attack. Continuous variables comprised: pre-exercise peak expiratory flow rate, height, weight for height index, ${ }^{11}$ sum of skinfolds (biceps, triceps, subscapular and suprailiac), skinfold distribution (the ratio of biceps + triceps to subscapular + suprailiac), systolic blood pressure, birth weight, father's body mass index, mother's body mass index, and mother's age at the child's birth. Log transformation was used for the weight for height index, sum of skinfold, skinfold distribution, father's body mass index, and mother's body mass index because each had positively skewed distribution.

Heights were measured to the last completed $0.1 \mathrm{~cm}$ using the method recommended by Tanner et al. ${ }^{12}$ Weights were measured in underpants and vest using Soehnle digital scales reading to $0 \cdot 1 \mathrm{~kg}$. Triceps, biceps, subscapular, and suprailiac skinfold thicknesses were measured with Harpenden skinfold callipers to the last completed $0.2 \mathrm{~mm}$. Triceps and subscapular skinfolds were measured according to the methods described by Cameron. ${ }^{13}$ The biceps measurement was made overlying the belly of the biceps muscle at the mid-point of a vertical line joining the head of the humerus with the mid-point of the cubital fossa. The suprailiac measurement was made in the midaxillary line, $2.5 \mathrm{~cm}$ above the iliac crest. Blood pressure was measured using the Dynamap 1846 automated sphygmomanometer with an

Table 1 Differences of the selected continuous variables between children who did and did not perform the test. (Values mean (SD).)

\begin{tabular}{|c|c|c|c|c|c|c|}
\hline $\begin{array}{l}\text { Test } \\
\text { status }\end{array}$ & No & $\begin{array}{l}\text { Height } \\
(\mathrm{cm})\end{array}$ & $\begin{array}{l}\text { Systolic blood } \\
\text { pressure }(\mathrm{mmHg})\end{array}$ & $\begin{array}{l}\text { Sum of } \\
\text { skinfold* }\end{array}$ & $\begin{array}{l}\text { Skinfold } \\
\text { distributiont }\end{array}$ & $\begin{array}{l}\text { No of } \\
\text { siblings }\end{array}$ \\
\hline Boys: & & & & & & \\
\hline $\begin{array}{l}\text { Performed } \\
\text { Did not perform } \\
\text { Girls. }\end{array}$ & $\begin{array}{c}297 \ddagger \\
74\end{array}$ & $\begin{array}{l}134 \cdot 17(6 \cdot 24) \\
133 \cdot 31(6 \cdot 60)\end{array}$ & $\begin{array}{l}109 \cdot 6(7 \cdot 9) \\
109 \cdot 3(8 \cdot 4)\end{array}$ & $\begin{array}{l}3 \cdot 44(0 \cdot 40) \\
3 \cdot 40(0 \cdot 40)\end{array}$ & $\begin{array}{l}0 \cdot 202(0 \cdot 219) \\
0 \cdot 197(0 \cdot 211)\end{array}$ & $\begin{array}{l}2 \cdot 64(1 \cdot 10) \\
2 \cdot 80(1 \cdot 25)\end{array}$ \\
\hline $\begin{array}{l}\text { Girls: } \\
\text { Performed } \\
\text { Did not perform }\end{array}$ & $\begin{array}{r}292 \\
74\end{array}$ & $\begin{array}{l}133 \cdot 43(5 \cdot 94) \\
132 \cdot 24(6 \cdot 72)\end{array}$ & $\begin{array}{l}110 \cdot 6(9 \cdot 4) \\
111 \cdot 5(9 \cdot 2)\end{array}$ & $\begin{array}{l}3.68(0.35) \\
3.65(0.34)\end{array}$ & $\begin{array}{l}0 \cdot 239(0.255) \\
0 \cdot 212(0 \cdot 252)\end{array}$ & $\begin{array}{l}2 \cdot 59(1 \cdot 20) \$ \\
3 \cdot 79(1 \cdot 14)\end{array}$ \\
\hline
\end{tabular}

${ }^{*} \log \{$ sum of skinfolds at biceps, triceps, subscapular and suprailiac $(\mathrm{mm})\}$.

$+\log \{$ sum of skinfolds at biceps, triceps, subscapular and suprailiac (mm) $\}$.
$+\log \{$ (sum of skinfolds at biceps and triceps)/(that at subscapular and suprailiac)\}.
The lowest number of the observed.

$\S \mathrm{p}<0.05$ performed test $v$ did not perform test.

For more details, see text. 
Table 2 Distribution of selected categorical variables in the children who did and did not perform the test (excluding ethnic minorities). (Values mean (SD).)

\begin{tabular}{|c|c|c|c|c|c|}
\hline \multirow[t]{2}{*}{ Test status } & \multicolumn{5}{|c|}{ Mother's education } \\
\hline & $\begin{array}{l}\text { Primary school } \\
\text { or none }\end{array}$ & Middle* & $\begin{array}{l}\text { University or } \\
\text { polytechnic }\end{array}$ & Unknown & Total \\
\hline \multirow{4}{*}{$\begin{array}{l}\text { Boys: } \\
\text { Performed } \\
\text { Did not perform } \\
\text { Girls: } \\
\text { Performed } \\
\text { Did not perform }\end{array}$} & $\begin{array}{ll}4 & (1 \cdot 3) \\
2 & (2 \cdot 4)\end{array}$ & $\begin{array}{r}189(61 \cdot 0) \\
59(70 \cdot 2)\end{array}$ & $\begin{array}{r}103(33 \cdot 2) \\
18(21 \cdot 4)\end{array}$ & $\begin{aligned} 14 & (4 \cdot 5) \\
5 & (6 \cdot 0)\end{aligned}$ & $\begin{array}{r}310(100 \cdot 0) \\
84(100 \cdot 0)\end{array}$ \\
\hline & $\begin{array}{ll}7 & (2 \cdot 3) \\
0 & (0 \cdot 0)\end{array}$ & $\begin{array}{r}183(60 \cdot 0) \\
44(55 \cdot 0)\end{array}$ & $\begin{array}{r}101(33 \cdot 1) \\
30(37 \cdot 5)\end{array}$ & $\begin{aligned} 14 & (4 \cdot 6) \\
6 & (7 \cdot 5)\end{aligned}$ & $\begin{array}{r}305(100 \cdot 0) \\
80(100 \cdot 0)\end{array}$ \\
\hline & \multicolumn{5}{|c|}{ Father's social class } \\
\hline & Manual & Non-manual & & Unknown & Total \\
\hline \multirow{4}{*}{$\begin{array}{l}\text { Boys: } \\
\text { Performed } \\
\text { Did not perform } \\
\text { Girls: } \\
\text { Performed } \\
\text { Did not perform }\end{array}$} & $\begin{array}{l}92(29 \cdot 7) \\
28(33 \cdot 3)\end{array}$ & $\begin{array}{r}149(48 \cdot 1) \\
32(38 \cdot 1)\end{array}$ & - & $\begin{array}{l}69(22 \cdot 3) \\
24(28 \cdot 6)\end{array}$ & $\begin{array}{r}310(100 \cdot 0) \\
84(100 \cdot 0)\end{array}$ \\
\hline & $\begin{array}{l}88(28 \cdot 3) \\
27(33 \cdot 8)\end{array}$ & $\begin{array}{r}129(42 \cdot 3) \\
32(40 \cdot 0)\end{array}$ & - & $\begin{array}{l}88(28 \cdot 9) \\
21(26 \cdot 3)\end{array}$ & $\begin{array}{r}305(100 \cdot 0) \\
80(100 \cdot 0)\end{array}$ \\
\hline & \multicolumn{5}{|c|}{ Parents' total home smoking (cigarettes/d) } \\
\hline & 0 & $1-10$ & 11 or more & Unknown & Total \\
\hline $\begin{array}{l}\text { Boys: } \\
\text { Performed } \\
\text { Did not perform } \\
\text { Girls: }\end{array}$ & $\begin{array}{r}176(56 \cdot 8) \\
49(58 \cdot 3)\end{array}$ & $\begin{array}{l}63(20 \cdot 3) \\
17(20 \cdot 2)\end{array}$ & $\begin{array}{l}55(17 \cdot 7) \\
14(16 \cdot 7)\end{array}$ & $\begin{aligned} 16 & (5 \cdot 2) \\
4 & (4 \cdot 8)\end{aligned}$ & $\begin{array}{r}310(100 \cdot 0) \\
84(100 \cdot 0)\end{array}$ \\
\hline $\begin{array}{l}\text { Performed } \\
\text { Did not perform }\end{array}$ & $\begin{array}{r}183(60 \cdot 0) \\
46(57 \cdot 5)\end{array}$ & $\begin{array}{l}61(20 \cdot 0) \\
16(20 \cdot 0)\end{array}$ & $\begin{array}{l}46(15 \cdot 1) \\
14(17 \cdot 5)\end{array}$ & $\begin{aligned} 15 & (4 \cdot 9) \\
4 & (5 \cdot 0)\end{aligned}$ & $\begin{array}{r}305(100 \cdot 0) \\
80(100 \cdot 0)\end{array}$ \\
\hline
\end{tabular}

Frequency $(\%) *$ Secondary education/commercial college/technical college/nursing

Table 3 Final model using multiple logistic regression with backward elimination to assess factors associated with termination of the cycloergometer test within four minutes

\begin{tabular}{|c|c|c|}
\hline & Coefficient (SEM) & $p$ \\
\hline \multicolumn{3}{|l|}{$\begin{array}{l}\text { Boys: (Dependent variable: whether he completed the } \\
\text { test }(=1) \text { or not }(=0) \text { ) }\end{array}$} \\
\hline Height $(\mathrm{cm})$ & $0.065(0.032)$ & $<0.05$ \\
\hline Systolic blood pressure $(\mathrm{mmHg})$ & $-0.046(0.024)$ & $<0 \cdot 10$ \\
\hline Constant & $-1 \cdot 330(4 \cdot 523)$ & - \\
\hline \multicolumn{3}{|c|}{$\begin{array}{l}\text { (An independent variable, number of siblings was not included in the model, because } 24 \text { boys } \\
\text { without siblings all completed the test.) }\end{array}$} \\
\hline \multicolumn{3}{|c|}{$\begin{array}{l}\text { Girls: (Dependent variable: whether she completed the } \\
\text { test }(=1) \text { or not }(=0) \text { ) }\end{array}$} \\
\hline Height $(\mathrm{cm})$ & $0.107(0.035)$ & $<0.005$ \\
\hline Systolic blood pressure $(\mathrm{mmHg})$ & $-0.053(0.022)$ & $<0.05$ \\
\hline Skinfold distribution* & $1.674(0.747)$ & $<0.05$ \\
\hline Constant & $-6 \cdot 438(4 \cdot 721)$ & - \\
\hline
\end{tabular}

${ }^{*} \log \{($ sum of skinfolds at biceps and triceps)/(that at subscapular and suprailiac)\} For more details, see text.
Table 4 The number of loads the child completed and PWC $85 \%$ (Watt/kg)

\begin{tabular}{lrl}
\hline Loads & No & Mean $(S D)$ \\
\hline Boys: & & \\
2 & 25 & $2.032(0.491)$ \\
3 & 242 & $2.671(0.503)$ \\
4 & 14 & $3.491(1.596)$ \\
Girls: & & \\
2 & 26 & $1.485(0.300)$ \\
3 & 233 & $2.168(0.453)$ \\
4 & 14 & $2.656(0.282)$ \\
\hline
\end{tabular}

inflatable cuff of small adult size. Three measurements were taken for each child and the mean of the three measurements calculated for the analysis. Peak expiratory flow rate was measured with the mini Wright peak flow meter. Each child was asked to blow as hard as possible three times before the cycle-ergometer test.

Two main analyses were carried out. A logistic regression was performed to assess the factors associated with termination of the test before four minutes, when PWC85\% could not be calculated. In this analysis, the dependent variable was whether or not the child completed the cycle-ergometer test. The independent variables were the following subset of variables given above: number of siblings, mother's home smoking, mother's smoking during pregnancy with the child, family history of heart attacks in parents and grandparents under the age of 65 , child's height, systolic blood pressure, preexercise peak expiratory flow rate, sum of skinfolds and skinfold distribution. The calculations were carried out using GLIM 3.77 with backward elimination until the $\mathrm{p}$ values of all the remaining independent variables were less than $0 \cdot 1$.

Multiple regression analyses were performed for each sex separately, with PWC85\% as dependent variable and as independent variables all those discussed above. Backward elimination of variables was carried out and the final model included only variables significant at $10 \%$ level.

\section{Results}

Figure 1 gives the response rate to the test. The parents of $15 \%$ of the boys and $16 \%$ of the girls did not give consent for the child to be measured. A further $25 \%$ of the children were not included in the analysis and the reasons are given in the figure. The ethnic minority group was excluded as analysis for this group will be carried out with an additional sample. There were $299(60 \%)$ boys and 282 $(57 \%)$ girls available for analysis from the eligible sample.

Tables 1 and 2 give the comparison of several variables between children who did and did not perform the test. The only significant difference ascertained was number of siblings in girls. 
Table 5 Final model using multiple regression with backward elimination to assess factors associated with PWC85\% (Values, mean (SD).) Estimate (SEM) p

Boys $(n=276)$ :

(Dependent variable: PWC85\% (Watt/kg)) Independent variables Sum of skinfolds*

Height $(\mathrm{cm})$ Skinfold distribution $†$ Intercept

$\begin{array}{rr}-0.555(0.098) & <0.001 \\ 0.021(0.006) & 0.001 \\ 0.412(0.098) & 0.019 \\ 1.682(0.856) & -\end{array}$

Girls ( $n=259)$ :

(Dependent variable: PWC85\% (Watt/kg))

Independent variables Sum of skinfolds $\{\log (\mathrm{mm})\}$ Height (cm)

Pre-exercise peak flow rateł

Family history of heart attack

Systolic blood pressure ( $\mathrm{mmHg}$ )

Mother's smoking during pregnancy

Intercept

* Log sum of skinfolds at biceps, triceps, subscapular and suprailiac (mm)\}

$+\log \{$ (sum of skinfolds at biceps and triceps)/(that at subscapular and suprailiac) $\}$

$¥(1 / \mathrm{min})$

For more details, see text. heart attacks $(\mathrm{p}<0.05)$, systolic blood pressure $(\mathrm{p}<0.05)$, and mother's smoking status during pregnancy with the child $(\mathrm{p}<0 \cdot 01)$. Children whose mothers smoked during pregnancy had higher PWC85\% values than those without information or those whose mothers did not smoke during pregnancy.

As none of the social factors was significantly associated with fitness in the final model of the multiple regression analysis, a single variable analysis was carried out between child's fitness of the sociodemographic variables size of sibship, and father's social class and current employment status. These variables were chosen out of all the social variables in the analysis because they have been found to be related to height and overweight in some studies and these factors might lie on a causal chain between social factors and differences in fitness. Only the size of sibship was just significantly associated with girl's fitness $(p<0.05)$ and this was of borderline significance for boys $(p<0 \cdot 1)$ (table 6). However, the association was negative in girls and positive in boys.

\section{Discussion}

In this analysis, physical fitness was assessed in terms of ability to complete at least four minutes of the test and the level of PWC $85 \%$. In both analyses the three most consistent factors associated with performance were height, sum of skinfolds, and blood pressure. Taller and thinner children, and those with low systolic blood pressure had better physical fitness than other children. Skinfold distribution was associated with fitness in two of the four analyses, indicating that children with relatively more fat in the arms than the body were fitter. Other measurement were inconsistently associated with fitness and social factors in general were not related to fitness. There was an unexpected result in that girls whose mothers smoked during pregnancy had a higher PWC $85 \%$.

The apparent low response rate of approximately $60 \%$ of the eligible children is misleading. Most children wanted to take part in the test. They could not participate either because their parents did not consent or for reasons unrelated to their wishes as shown in figure 1. Parents who did not give consent for their child to participate in the fitness test did so for all the tests. Though the possibility of

Table 6 Mean (SEM) of PWC85\% (Watt/kg) in relation to sociodemographic factors

\begin{tabular}{|c|c|c|c|c|c|}
\hline & $\begin{array}{l}\text { Boys } \\
\text { No }\end{array}$ & Mean (SEM) & $\begin{array}{l}\text { Girls } \\
\text { No }\end{array}$ & Mean (SEM) & $p$ \\
\hline \multicolumn{6}{|l|}{ Size of sibship: } \\
\hline 1 & 24 & $2 \cdot 54(0 \cdot 14)$ & 22 & $2 \cdot 40(0 \cdot 15)$ & \multirow{5}{*}{$\mathrm{p}<0.05$} \\
\hline 2 & 125 & $2.57(0.05)$ & 133 & $2.08(0.04)$ & \\
\hline 3 or 4 & 111 & $2.75(0.07)$ & 91 & $2 \cdot 14(0.05)$ & \\
\hline 5 or over & 14 & $2.95(0.14)$ & 16 & $2 \cdot 16(0 \cdot 11)$ & \\
\hline Not known & 7 & $2.53(0.20)$ & 11 & $1.92(0.12)$ & \\
\hline \multicolumn{6}{|c|}{ Father's social class: } \\
\hline Non-manual & 59 & $2.75(0.07)$ & 77 & $2 \cdot 13(0.05)$ & \\
\hline Manual & 137 & $2.64(0.07)$ & 116 & $2 \cdot 14(0.04)$ & \\
\hline Not known & 85 & $2.61(0.05)$ & 80 & $2 \cdot 11(0.06)$ & \\
\hline \multicolumn{6}{|c|}{ Father's employment: } \\
\hline Employed & 207 & $2.64(0.05)$ & 193 & $2 \cdot 11(0 \cdot 04)$ & \\
\hline Unemployed & 28 & $2 \cdot 62(0 \cdot 10)$ & 21 & $2.37(0 \cdot 10)$ & \\
\hline Not known & 46 & $2.73(0.08)$ & 59 & $2 \cdot 11(0.06)$ & \\
\hline
\end{tabular}


bias cannot be discounted, the only probable source of bias was the $15 \%$ of children whose parents did not give consent to measure their child. Comparison of several variables showed no remarkable differences between children who performed and did not perform the test. We believe that our results genuinely assessed fitness in our study and not, for example, mechanical advantage of the tall because the cycle was adjustable to the child's height.

In the pilot stage of the study we compared two possible fitness tests: the $20 \mathrm{~m}$ shuttle run and the cycle-ergometer test. Both have been shown to have a high correlation with the $\mathrm{VO}_{2} \max ,{ }^{1014}$ which is considered to be the gold standard. ${ }^{15}$ However, there is evidence that in 11 to 14 year olds the $20 \mathrm{~m}$ shuttle run has a low correlation with $\mathrm{VO}_{2} \max ,{ }^{16}$ while PWC75\%, which is almost the same marker as PWC $85 \%$, has a strong correlation (correlation coefficient $=0.924, \mathrm{n}=16$ ) with $\mathrm{VO}_{2} \max$ in 8-12 year old children. ${ }^{17}$ In the pilot study we were unhappy with the $20 \mathrm{~m}$ shuttle run because instantaneous assessment of pulse rate was not feasible and we were unsure of the level of commitment to the test of some children. After piloting the cycle-ergometer twice and modifying the procedure to make it appropriate for children below 10 years of age we seldom had difficulty during the fieldwork except that the cycle-ergometer broke down several times.

There are few studies assessing both the biological and social factors associated with fitness in children. In Britain, even in adults, the main concern has been to provide a valid measure of physical fitness and to give baseline results. Baseline information on fitness has been published for British adults in the national fitness survey ${ }^{1}$ and for adolescents in a study in the south west of England. ${ }^{23}$ There are several studies in children and adolescents in Europe and the USA that have shown an association between physical activity and other measurements such as height, ${ }^{2}$ weight, ${ }^{18}$ skinfolds at four sites, ${ }^{2}$ blood pressure ${ }^{1819}$ and lipoproteins. ${ }^{20}$ There is information that physical training for 8 months increases $\mathrm{VO}_{2} \mathrm{max}$ and decreases blood pressure. ${ }^{19}$ Despite the uncertainty of the level of association between physical activity and fitness in children and adolescents, ${ }^{3}$ it is reassuring in the current study that factors found to be associated with physical activity elsewhere are also associated with fitness in children. It is also in agreement with studies in adults that have shown taller and thinner subjects to be fitter. ${ }^{1}$

We are not aware that others have shown that the ratio of subcutaneous tissue between the arms and the body, based on skinfold calliper measurements, is related to an increased physical fitness. However, an association has been shown between sports activity and the waist/hip ratio. ${ }^{21}$ The arm/body ratio, based on skinfold measurements, and the hip/waist ratio could be considered equivalent as both attempt to assess fat distribution. This may be a potentially important finding as it has been reported that in adults the fat distribution is associated with mortality for cardiovascular dis- ease. ${ }^{22}$ However, even if this finding were confirmed its practical relevance is doubtful as we are uncertain about our ability to modify fat distribution.

Although there were other factors associated with fitness such as maternal smoking in pregnancy, premature heart attacks in parents and grandparents, and the number of siblings, the inconsistency of the associations throughout the analyses and the lack of reports from other studies does not allow us to highlight these findings.

Despite the large number of socioeconomic variables in the study, we were unable to find a single significant association between social factors and physical fitness in the multiple regression analysis. There was a significant association (just) in girls and one of borderline significance in boys between fitness and the size of sibship in the univariate analysis. However, these associations were not consistent as one was positive in boys and negative in girls. Few researchers have studied the social factors influencing physical fitness. There is some information from Colombia showing that children from lower social classes have lower $\mathrm{VO}_{2} \mathrm{max}$ than children from upper social classes. ${ }^{23}$ However it is difficult to know to what extent this finding is relevant to the British social stratification.

In conclusion, children who are small, fat, have higher systolic blood pressure, and have relatively more fat in the body than the arms, tend to have poorer cardiorespiratory fitness. Although we cannot claim causality from this cross sectional analysis, the consistency of most of these finding in the published reports and the report of a randomised controlled trial showing that training can increase $\mathrm{VO}_{2}$ max and reduce blood pressure, support a view that these variables influence each other. If this is correct, increased physical activity in childhood can be developed as an avenue for preventing a coronary heart condition in adulthood.

The study was funded by the Department of Health and the Scottish Home and Health Department. We are indebted to Professor WW Holland for the support and Dr J Hammond, $\mathrm{Dr} W$ Tuxworth and his colleagues for their invaluable advice and help in the pilot stage of the study. S Kikuchi was a visiting fellow in the Department of Public Health Medicine (UMDS).

1 Sports Council. Allied Dunbar national fitness survey (summary). London: Health Education Authority, 1992:1-11. mary). Londerns of Armstrong, N, Balding J, Gentle P, Kirby British children. physical activity among

3 Armstrong N, Balding J, Gentle P, Williams J, Kirby B. Peak oxygen uptake and physical activity in 11 to 16 year olds. Pediatric Exercise Science 1990;2:349-58.

4 Cale L, Almond L. Monitoring physical activity in children. Proceedings of children's activity and health seminar. Loughborough: Loughborough University, 1991.

5 Siscovick DS. Laporte RE, Newman JM. The diseasespecific benefits and risks of physical activity and exercise. Public Health Rep 1985;100:180-8.

6 Gulliford MC, Chinn S, Rona RJ. Social environment and Gulliford MC, Chinn S, Rona RJ. Social environment and Child 1991;66:235-40.

7 Rona RJ, Chinn S. National Study of Health and Growth: social and family factors and obesity in primary school children. Ann Hum Biol 1982;9:131-45.

8 Chinn S, Rona RJ. The secular trend in the height of primary school children in England and Scotland 1972 to 1980. Ann Hum Biol 1984;11:17-28.

9 Chinn S, Rona RJ. Trends in weight-for-height and triceps skin-fold thickness in English and Scottish children 1972-82 and 1982-90. Paediat Perinatal Epidemiol 1994; 8:90-106. 
10 Committee for the Development of Sport. Eurfit: European test of physical fitness. Rome: Council of Europe 1988: 30-9.

12 Tanner JM, Whitehouse RH, Takaishi M. Standards from birth to maturity for height, weight, height velocity and weight velocity: British children 1965. Parts I and II. Arch Dis Child 1966;41:454-71, 613-35.

13 Cameron N. The methods of auxological anthropometry. In: Falkner F, Tanner JM eds. Human growth, a comprehensive treatise, Vol 3: Methodology, ecologic, genetic and nutritional effects on growth. New York: Plenum Press, 1986:3-46.

14 Leger LA, Lambert J. A maximal multistage 20-m shuttle run test to predict $\mathrm{VO}_{2} \max$. Eur $\mathcal{F}$ Appl Physiol 1982;49. $1-12$

15 Smith GD, Morris JN. Editorial. Assessment of physical activity and physical fitness in population surveys. $\mathcal{f} E p$ idemiol Community Health 1992;46:89-91.

16 Armstrong N, Williams J, Ringham D. Peak oxygen uptake and progressive shuttle run performance in boys aged 11-14 years. British fournal of Physical Education 1988; 19(res suppl 4):10-11.

17 Tamiya N. Study of physical fitness in children and its application to paediatric clinics and sports medicine (in Japanese). Hokkaido Igaku Zassi 1991;66:849-67.
18 Strazzullo P, Capuccio FP, Trevisan $M$ et al. Leisure time, physical activity and blood pressure in school children. Am ₹ Epidemiol 1988;127:726-33.

19 Hensen HS, Froberg K. Hyldebrand N, Nielsen JR. A controlled study of eight months of physical training and reduction of blood pressure in children: The Odense school child study. BMF 1991;303:682-5.

20 Durant $\mathrm{RH}$, Linder $\mathrm{CW}$ and Mahoney $\mathrm{OM}$. The relationship between habitual physical activity and serum lipoproteins in white male adolescent. $\mathcal{f}$ Adolescent Health Care 1983;4:235-9.

21 Seidell JC, Cigolini M, Deslypere J-P, Charzewska J, Ellsinger B-M, Cruz A. Body fat distribution in relation to physical activity and smoking habits in 38-year-old European men. Am f Epidemiol 1991;133:257-65.

22 Lapidus L, Bengtsson C, Larsson B, Pennert K, Rybo E, Sjostrom L. Distribution of adipose tissue and risk of cardiovascular disease and death: a 12 year follow up of participants in the population study of women in Gothenburg, Sweden. BMF 1984;289:1257-61.

23 Spurr BG, Reina JC, Dahners HW, Barac-Nieto $M$. Marginal malnutrition in school-aged Colombian boys: functional consequences in maximum exercise. $A m \mathcal{F}$ Clin $N_{u t}$ 1983;37:834-47. 